\title{
AGRIBUSINESS DEVELOPMENT STRATEGY OF SOYBEAN COMMODITY IN SIGI REGENCY
}

\author{
Eru Rengga Patra ${ }^{1)}$, Lien Damayanti ${ }^{2)}$, Yulianti Kalaba ${ }^{2)}$ \\ ${ }^{1)}$ Student of Agribusiness Study Program of Agriculture Faculty of Tadulako University, Palu \\ e-mail : erpatra07@gmail.com \\ ${ }^{2)}$ Lecturer and Researcher at Department of Agribusiness Faculty of Agriculture University of Tadulako, Palu
}

\begin{abstract}
This research aimed to: 1) Knowing the strengths, weaknesses, opportunities and threats for agribusiness development of soybean commodity in Sigi Regency; 2) Knowing the right alternative strategy formula for the development of soybean commodity agribusiness in Sigi Regency; 3) Knowing the priority strategy that should be chosen for the agribusiness development of commodity soybean in Sigi Regency. This research purposively conducted in Sigi Regency from January to March 2017, and 6 respondents were chosen. SWOT analysis used to find alternative strategy, and QSPM analysis used to find priority strategy. The availability and productivity of the land is among the main strenghts, and the quality and quantity of human resources is among the main weaknesses.The main opportunity is the price of soybean commodity in the market, while imports of soybeans by the government is the main threats. The alternative and priority strategy that could be undertaken by the governmenr are : 1) Participatory motivation and farmers empowerment program; 2) Strengthening local soybean development policy that is pro-farmer; 3) Soybean cultivation development program through area expansion and land mapping; 4) Regional Agricultural Partnership; 5) Development of soybean processing industry.
\end{abstract}

Key Words : Soybean, sigi, SWOT, QSPM.

\section{INTRODUCTION}

Achieving national food security has a strategic meaning related to social security, economic stability, political stability, national security, and national independence. The desire of the government and the people of Indonesia to realize solid food security is reflected in the existence of the Food Act. In Law no. 18 of 2012 on Food, expressly mandates the need for Indonesia to build self-sustaining and sovereign food security. The achievement of food security can be measured through four indicators, namely, (a) food availability adequacy; (B) the stability of food availability; (C) accessibility to food; And (d) quality including food safety (Rachmat, 2015).

Efforts to increase the ability of domestic food production (self-sufficiency), stabilization of food prices, and reduce dependence on imports in order to avoid the food crisis has always been the main focus of government. The government continues to achieve self-sufficiency in food, not only for rice but also for corn, soybeans, sugar, and beef (Yudhoyono, 2010). According to Budhi and Aminah (2010), the importance of Indonesia to self-sufficiency of soybeans is at least based on two arguments. First, soy is a cheap source of protein for the people of Indonesia, which has lasted very long. Without producing that meets the amount of demand, it will be a weak point that can affect various aspects, including social, economic and political. Second, the inability to self-sufficiency will spend the foreign exchange which can be the weak point of the country in the broader aspect and spectrum. The waste of foreign exchange to import soybeans is a step backward, because foreign exchange can be used for 
more strategic purposes and has multiplier effects, for example for the development of manufacturing that can absorb labor from the agricultural sector, and support the transformation of the agricultural sector into non agricultural sector that more productive.

Currently, Indonesia is the world's sixth largest producer of soybeans after the United States, Brazil, Argentina, China and India. However, domestic soybean production has not been able to meet the increasing domestic demand from time to time well beyond the increase in domestic production. To be sufficient, the government imports (Nasution, 1990; Zakaria, 2010). More than half of the domestic soybean needs are still met from imports. The main factor causing the high import of soybean is the low domestic soybean production. Soya production in Indonesia has fluctuated in recent years. National soybean production in 2015, which only reached 963,943 thousand tons, is much different when compared to the relatively high volume of soybean imports in 2015 of 1.67 million tons (Kementan, 2015).

The policy of agricultural development through the Agribusiness Development Program is one of the government's seriousness in increasing the production of soybean, either through the expansion of planting area, increasing productivity and providing government support through policies that favor the farmers, such as the soybean trade regulation, import tariff and pricing basic. The policy is expected to motivate farmers to participate in the development of soybean agribusiness, especially in the eastern part of Indonesia which has considerable land potential for soybean cultivation (Zakaria, 2010).

According to the Central Bureau of Statistics (BPS, 2016), Indonesia's soybean productivity in 2015 is $15.68 \mathrm{kw} \mathrm{/} \mathrm{ha.}$ Central Sulawesi in this case has the highest productivity among all provinces in Indonesia with $18.71 \mathrm{kw} /$ ha (up from 2014 at $16.18 \mathrm{kw} / \mathrm{ha}$ ), even indicating soybean productivity in Central Sulawesi above the national soybean productivity average. This shows that there is a huge potential for soybean development in Central Sulawesi. Soybean production in Central Sulawesi in 2014 is 16,399 tons or increased compared to 2013 only about 12,000 tons. Tojo Unauna, Banggai and Parigi Moutong districts are the largest contributors to soybeans in Central Sulawesi. Sigi regency in 2014 can only contribute 2 tons of soybeans from total domestic production. Sigi district soybean production is the lowest, in addition to Banggai Laut and Palu districts that do not contribute to soybean production at least because of the absence of soybean development areas in the area.

Central Sulawesi Provincial Government in 2015 prioritizes the development of soybean in four main areas (in this case the lowest production area, and has good land potential), namely Buol, Sigi, Banggai Laut and Palu. In Sigi district, the development of soybean is only two hectares, so in 2015 the Central Sulawesi Provincial Government provides land for the development of 6,500 hectares of soybean for the four areas (Lamakampali, 2015).

Based on the background that has been described above, the formulation of the problem in this study is, (1) How Sigi District Government utilizes the strengths, weaknesses, opportunities and threats for the development of agribusiness soybean commodities? (2) What is the right alternative strategy formula for the development of soybean commodity agribusiness in Sigi Regency? (3) How should the strategy priority be chosen for the development of soybean commodity agribusiness in Sigi district?. This research aimed to: 1) Knowing the strengths, weaknesses, opportunities and threats for agribusiness development of soybean commodity in Sigi Regency; 2) Knowing the right alternative strategy formula for the development of soybean commodity agribusiness in Sigi Regency; 3) Knowing the priority strategy that should be chosen for the agribusiness development of commodity soybean in Sigi Regency. 


\section{RESEARCH METHODS}

This research was conducted in Sigi Regency which was done purposively because Sigi Regency is one of the area for the development of soybean production in Central Sulawesi (as described in the research background). The types of data used are primary and secondary data. The primary data were obtained from interviews by experts. Secondary data were obtained from the archives of the agriculture department and the Central Bureau of Statistics (BPS) of Sigi and Central Sulawesi districts, literature books, journals, as well as tracing information via the internet that could support the research.

Sampling using Judgmental Sampling, which is a sampling technique performed based on the characteristics set against target population elements tailored to the objectives and research problems. The sample size in each sub-population is determined by the researchers to a certain amount (Amirin, 2010). Respondents consisted of 6 people consisting of 3 people from the agricultural sector of Sigi Regency and 3 farmers of Sigi Regency. Respondents were selected because they were considered competent and understood the development of soybean commodity in Sigi Regency. The respondents in this research are: 1 person from Agricultural Extension Division in Sigi Regency, 1 person from Food Crops and Horticulture Department of Agriculture of Sigi District, 1 person from UPT Germination of Food Crops and Horticulture Department of Sigi Regency, and 3 farmers who are the chairman Farmer Group or Joint Farmer Group in Sigi Regency.

Technique of collecting data and information done by observation, interview, and filling questionnaire. Data analysis methods used include Internal Factor Evaluation (IFE) analysis, External Factor Evaluation (EFE) analysis, Strengths, Weaknesses, Opportunities and Threats (SWOT) analysis, and strategy priority selection using Quantitative Strategic Planning Matrix (QSPM) analysis.
Descriptive analysis is used to explain the vision and mission of soybean commodity development in Sigi Regency. IFE and EFE are used to analyze internal and external factors that influence the strategy of developing soybean commodities (Rangkuti, 2015). SWOT analysis to formulate alternative strategies and QSPM to gain strategic priority (David, 2012). Sigi regency is one of choice as central of soybean commodity development in Central Sulawesi. The strategic location of Sigi Regency has a good potential for the development of the soybean commodity sector.

\section{RESULTS AND DISCUSSION}

\section{Internal and External Identification.} The results of field observations and interviews and questionnaires to the respondents obtained some of the result factors that make up the IFE analysis (strengths and weaknesses) and EFE (opportunities and threats). Here are the results of all internal and external factors after being combined.

Internal Factors. Based on the research results found that the factors that become astrenght in the development of soybean commodities are as follows: (1). Geographical Compatibility; (2) Institutional management of farmers; (3) Land Availability and Productivity; (4) Solidity of Agricultural Apparatus and Related Institution; (5). Program Development Planning. Internal factors that become weakness in the development of soybean commodity agribusiness in Sigi District, namely: (1). Quality and Quantity of Human Resources still low; (2) Facilities and Infrastructure not yet supported; (3) Lack Application of Agricultural Machinery Technology; (4). Weak Financial Capacity; (5). Lack of Agribusiness Business Actor.More details about the evaluation of internal factors can be seen in the IFAS matrix (Internal Factor Analysis Summary) Table 1.

External Factors. Based on the results of interviews with expert respondents and field observations, the external factors of opportunities are as follows: (1) Sigi Regency Government Policy; (2) Increasing 
Demand and Consumption of Soybean; (3) Availability of Superior Seed Varieties; (4) Central Government Support for Soybean Development; (5) Soybean Prices on the Market. Factors that serve as a threat in the development of agribusiness soybean commodity in Sigi Regency are as follows: (1). Price fluctuations in production inputs;
(2) Import of Soybean by the Government;

(3) The existence of Substitution Products;

(4) Climate Change and the presence of Plant Disease Organisms; (5) Soybean Farming System.Evaluation of opportunity and threat factors can be seen in EFAS (External Factor Analysis Summary) matrix Table 2.

Table 1. IFAS Matrix Analysis of Agribusiness Development of Soybean Commodity in Sigi Regency

\begin{tabular}{|c|c|c|c|}
\hline Internal Factors Strategy & Weight & Rating & Weighted Score \\
\hline \multicolumn{4}{|l|}{ I. Strengths } \\
\hline a. Geographical Compatibility & 0,085 & 3 & 0,255 \\
\hline b. Institutional management of farmers & 0,094 & 3 & 0,282 \\
\hline c. Land Availibility and Productivity & 0,094 & 3 & 0,282 \\
\hline d. Solidity of Agricultural Apparatus & 0,094 & 3 & 0,282 \\
\hline e. Program Development Planning & 0,089 & 3 & 0,267 \\
\hline Total I & 0,456 & 15 & 1,368 \\
\hline \multicolumn{4}{|l|}{ II. Weakness } \\
\hline a. Quality and Quantity of Human Resources Still Low & 0,115 & 4 & 0,46 \\
\hline b. Facilities and Infrastructure not yet supported & 0,115 & 4 & 0,46 \\
\hline c. Lack of Application of Agricultural Machinery Technology & 0,115 & 4 & 0,46 \\
\hline d. Weak Financial Capacity & 0,097 & 3 & 0,291 \\
\hline e. Lack of Agribussines Business Actor & 0,103 & 4 & 0,412 \\
\hline Total II & 0,545 & 19 & 2,083 \\
\hline Total & 1,00 & & \\
\hline
\end{tabular}

Source: Primary Data After Processed, 2016.

Table 2. EFAS Matrix Analysis of Agribusiness Development of Soybean Commodity in Sigi Regency

\begin{tabular}{lccc}
\hline \multicolumn{1}{c}{ External Factors Strategy } & Weight & Rating & Weighted Score \\
\hline I. Opportunities & & & 0,086 \\
a. Sigi Regency Government Policy & 0,090 & 3 & 0,270 \\
b. Increasing Demand and Consumption of Soybean & 0,092 & 3 & 0,277 \\
c. Availibility of Superior Seeds Varieties & 0,083 & 3 & 0,250 \\
d. Central Government Support for Soybean Development & 0,108 & 4 & 0,433 \\
e. Soybean Prices on the Market & 0,460 & 16 & 1,488 \\
\hline \multicolumn{2}{c}{ Sub Total I } & & 0,103 \\
\hline II. Threats & 0,112 & 4 & 0,449 \\
a. Price fluctuations in production inputs & 0,104 & 3 & 0,311 \\
b. Import of Soybean by the Government & 0,108 & 4 & 0,433 \\
c. The existence of Substitution Products & 0,108 & 4 & 0,433 \\
d. Climate Change and the presence of Plant Disease Organisms & 0,535 & 18 & 1,935 \\
e. Soybean Farming System & 1,00 & & \\
\hline
\end{tabular}

Source: Primary Data After Processed, 2016. 


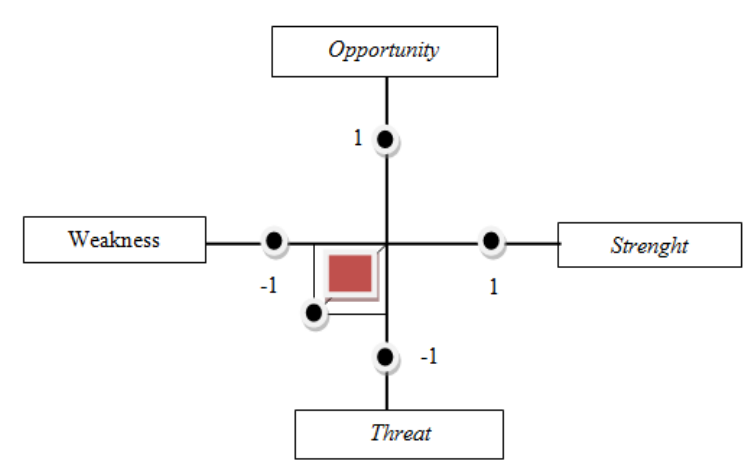

Figure 1. Diagram of SWOT Analysis of Soybean Development in Sigi District, Adapted from (Rangkuti, 2015).

Based on IFAS and EFAS matrix results it is found that internal strength factor score is 1.368 , and internal weakness score score is 2.083 . While the probability score is 1.488 , and the score for external threat factor is 1.935. The results of the scores of the IFAS and EFAS matrices are then analyzed into the SWOT analysis diagram, aiming to find out the strategies used to describe the current position of soybean commodity conditions in Sigi District.

Strategy calculation requires an affirmation of a position in the cross of the axis between the forces and weaknesses, as well as the opportunities and threats that are all depicted in positive and negative lines. Based on the SWOT analysis diagram in Figure 1, it is known that the current development of soybean commodity in sigi district in a defensive position.

Table 3. SWOT Matrix

\begin{tabular}{|c|c|c|}
\hline & Strenghts & Weaknesses \\
\hline & $\begin{array}{l}\text { 1. G eographical Compatibility } \\
\text { 2. Institutional management of } \\
\text { farmers } \\
\text { 3. Land Availibility and } \\
\text { Productivity } \\
\text { 4. Solidity of Agricultural } \\
\text { Apparatus and Related Institution } \\
\text { 5. Program Development Planning }\end{array}$ & $\begin{array}{l}\text { 1. Quality and Quantity of } \\
\text { Human Resources still low } \\
\text { 2. Facilities and Infrastructure } \\
\text { not yet supported } \\
\text { 3. Lack of Application of } \\
\text { Agricultural Machinery } \\
\text { Technology } \\
\text { 4. Weak Financial Capacity } \\
\text { 5. Lack of Agribussines Business } \\
\text { Actor }\end{array}$ \\
\hline Opportunities & SO Strategy & WO Strategy \\
\hline $\begin{array}{l}\text { 1. Sigi Regency Government } \\
\text { Policy } \\
\text { 2. Increasing Demand and } \\
\text { Consumption of Soybean } \\
\text { 3. Availibility of Superior Seeds } \\
\text { Varieties } \\
\text { 4. Central Government Support } \\
\text { for Soybean Development } \\
\text { 5. Program Development Planning }\end{array}$ & $\begin{array}{l}\text { 1. Soybean cultivation development } \\
\text { program through area expansion } \\
\text { and land mapping. } \\
\text { 2. Regional Agricultural Partnership }\end{array}$ & $\begin{array}{l}\text { 3. Participatory motivation and } \\
\text { farmers empowerment } \\
\text { program } \\
\text { 4. Implementation of pro-farm } \\
\text { price subsidy policy } \\
\text { 5. Increased financial access to } \\
\text { financial institutions } \\
\text { 6. Revitalization of agricultural } \\
\text { facilities and infrastructure }\end{array}$ \\
\hline Threats & ST Strategy & WT Strategy \\
\hline $\begin{array}{l}\text { 1. Price fluctuations in } \\
\text { production inputs } \\
\text { 2. Import of Soybean by the } \\
\text { Government } \\
\text { 3. The existence of Substitution } \\
\text { Products } \\
\text { 4. Climate Change and the } \\
\text { presence of Plant Disease } \\
\text { Organisms } \\
\text { 5. Soybean Farming System }\end{array}$ & $\begin{array}{l}\text { 7. Strengthening local soybean } \\
\text { development policies that are in } \\
\text { favor of the farmers } \\
\text { 8. Facilitate farmers in marketing } \\
\text { their production }\end{array}$ & $\begin{array}{l}\text { 9. Increasing the quality of } \\
\text { human resources of extension } \\
\text { workers and farmers } \\
\text { 10. Development of soybean } \\
\text { processing industry }\end{array}$ \\
\hline
\end{tabular}

Source: Primary Data After Processed, 2016. 
Alternative Strategy of Agribusiness Development of Soybean Commodity in Sigi Regency (SWOT Analysis). SWOT Matrix analysis results that are useful in formulating alternative strategies of soybean commodity development based on internal and external factors that have been previously identified are shown in Table 3.

Based on the results of SWOT matrix analysis in getting ten alternative strategies that can be used in the development of agribusiness soybean commodity in Sigi District. Consideration of these ten strategies into alternative strategies based on discussions and interviews with expert respondents associated with research purposes. The reason for the choice of strategy is also reinforced by considering the condition of soybean in Sigi regency which is currently in a defensive condition. The tenth strategies are as follows: (1). Development program of soybean cultivation specification through area extension and land mapping; (2). Regional Agricultural Partnership; (3). Programs motivate farmers' participation and empowerment; (4). Implementation of pro-farm price prosubsidy policy; (5). Increased financial access to financial institutions; (6). Revitalization of agricultural facilities and infrastructure; (7). Strengthening regional soybean development policies that favor farmers; (8). Facilitate farmers in marketing their production; (9). Increasing the quality of human resources of extension workers and farmers; (10). Development of soybean processing industry.

\section{Priority Strategy of Soybean Commodity} Development in Sigi Regency (QSPM Analysis). The analysis using SWOT matrix resulted in ten alternative strategic plans which will then be analyzed by using QSPM matrix to get the chosen strategy based on its priority level, that is based on the weight of its importance multiplied by its attractiveness value to all internal and external factors of soybean agribusiness.
Table 4. Results of QSPM Matrix Analysis

\begin{tabular}{clc}
\hline Priority & \multicolumn{1}{c}{ Alternative Strategy } & $\begin{array}{c}\text { TAS } \\
\text { Score }\end{array}$ \\
\hline 1 & $\begin{array}{l}\text { Programs motivate farmers' } \\
\text { participation and empowerment }\end{array}$ & 5.765 \\
2 & $\begin{array}{l}\text { Strengthening regional soybean } \\
\text { development policies that favor } \\
\text { farmers }\end{array}$ & 5.251 \\
3 & $\begin{array}{l}\text { Development program of soybean } \\
\text { cultivation specification through } \\
\text { area extension and land mapping }\end{array}$ & 4.695 \\
4 & $\begin{array}{l}\text { Regional Agricultural Partnership } \\
\text { Development of soybean } \\
\text { processing industry }\end{array}$ & 4.483 \\
\hline
\end{tabular}

Source: Primary Data After Processed, 2017.

Programs Motivate Farmers' Participation and Empowerment. The strategy of the program approach to farmers as the main actors is very instrumental in supporting the success of soybean development in Sigi Regency. Soy farmers in Sigi regency are very poor, farmers tend to avoid soybean cultivation due to lack of knowledge and experience. In order for the approach strategy to work properly, Hamdani (2006) argues that it needs to be carried out through two processes: 1) the process of stimulating or motivating the peasant community to participate in the development program, and 2) the empowerment process to build the quality of human resources.

After the process of approach has been going well, harmonious relationship between agricultural bureaucrats and farmers has been established, with the implementation of this program motivate and empower farmers can be done. However, the effort to motivate farmers to participate in the development of soybean needs to be done with appropriate methods. Activities begin with identification of development areas, analysis of comparative farming, local trials, demonstration plots, broader promotion, preparation of training modules and joint venture plans, and providing production factors in groups. Effective participation patterns need to be supported by collaborative skills in the grouping of farmer groups, as a social system and interaction media for behavior change through the adoption of relevant values, technologies and structures (Adjid, 1985; Zakaria, 2010). 
Farmers' decisions in participating are also influenced by favorable or disadvantageous economic circumstances. The farmer certainly wants his farming business to provide the highest benefits from the resources he manages. The productivity of farming resources depends on the technology applied. The ability and willingness of the farmers in terms of adopting the recommended cultivation technology is the absolute requirement for the development of agriculture in an area.

\begin{abstract}
Strengthening Regional Soybean Development Policies That Favor Farmers. The success of soy intensification is based on three basic assumptions, namely: 1) Better effort is needed to involve farmers in the development of soybean; 2) Many farmers are abandoning soybean farming due to various factors, both internal and external; And 3) Farmers with government and other stakeholders will play an important role in the development of soybean. To increase soybean production as well as to empower farmers, it is necessary to provide facilities for assistance, strengthening capital, training and guidance so that farmers will cooperate and able to apply recommended technology, and policies that protect farmers. Farmer participation is the determinant of successful soybean development (Zakaria, 2010).
\end{abstract}

\footnotetext{
Development Program of Soybean Cultivation Specification Through Area Extension and Land Mapping. The status of soybean crops as a companion commodity of Sigi Regency needs special attention. The seriousness of local government in the development of this commodity is expected, the intensification of soybean cultivation by utilizing the availability of superior seed varieties can be used as one way. Identification of specific areas of soybean commodity development in the villages needs to be done, so that the government is not wrong in implementing future programs. The main technologies needed in increasing productivity are the use of superior quality seed varieties, integrated weed and pest control, improving the fertility of the soil by fertilizing as needed (site-specific), appropriate planting time / season and crop rotation.
}

Synergy Regional Agricultural Partnership. Partnership development is an effort to grow or develop cooperation between farmers with private and other stakeholders engaged in agribusiness, from upstream to downstream (entrepreneur saprodi, seed breeders, companies, yield managers, trade), and other financial institutions. With the coordination between stakeholders, it is expected that the synergistic relationship between the agribusiness subsystem will run perfectly.

\section{Development of Soybean Processing}

Industry. The development of agroindustrybased soybean commodities requires a supportive business environment. This effort is the duty of the local government as an agricultural bureaucrat, which is expected to be a director and service provider. Processing of soybean commodities into value-added materials needs to be a special attention for the government to empower farmers into a creative economy society. Farmers and small-scale agribusiness entrepreneurs need organizations that are able to accommodate the idea ofagribusiness development. Some things that can be done by the local government in helping the development of soybean agroindustry is, by creating a mechanism of relationship between farmers and agro-industry business actors and provide insight into management and entrepreneurship, as well as providing capital and technology. In particular, Saragih (2010) argues that institutional support in the areas of information, research and education is necessary. Farmer organizations, in this case can cooperate with universities.

\section{CONCLUSIONS AND RECOMMENDATIONS}

\section{Conclusions}

Based on the results and previous discussion can be concluded that the current development of soybean commodity in Sigi Regency in a condition of survival. The position is not profitable, the identification of internal and external factors (IFE and EFE) proves that Sigi Regency as a whole has the weakness that must be minimized by exploiting the opportunities and strengths 
to avoid threats. One of the weakness factors in the spotlight is the lack of farmers (farmers) soybean. Various factors affecting farmers in Sigi Regency are reluctant to cultivate Soybean.

The result of SWOT (StrengthWeakness-Opportunity-Threat) matrix analysis using the internal and external factors that have been identified before, found 10 alternative design strategies that can be used for the development of soybean commodity. Furthermore, the ten alternative strategies are re-analyzed by using quantitative planning matrix analysis (QSPM) to generate priority of agribusiness development strategy of soybean commodity in Sigi regency. The five priority strategies are sequentially, namely: 1) Programs motivate farmers' participation and empowerment; 2) Strengthening local soybean development policies that are in favor of farmers; 3) Development program of soybean cultivation specification through area extension and land mapping; 4) Regional Agricultural Partnership; 5) Development of soybean processing industry.

\section{Recommendations}

Based on the research results some suggestions that can be recommended as follows,:

1. Sigi district government can develop agribusiness of soybean commodity through several programs such as, by providing training to motivate farmer participation and empowerment, conduct specification of soybean cultivation through land mapping to villages with better potency of land, development of regional agriculture partnership, and development of facilities Supporting the soybean processing industry.

2. As for further researchers interested in conducting research in the same field is expected to review the application of strategies that have been recommended.

\section{REFERENCES}

Amirin, T. M. 2011. Pokok-pokok Teori Sistem. PT Raja Grafindo Persada, Jakarta.

Badan Pusat Statistik (BPS) Sulawesi Tengah. 2015. Sulawesi Tengah Dalam Angka 2015.

Badan Pusat Statistik (BPS). 2016. Prodduktivitas Kedelai Menurut Provinsi (kw/ha), 1993-2015. Di akses melalui (https://www.bps.go.id) pada tanggal 27 Maret 2017.

Budhi, G. S., dan Mimin A. 2010. Swasembada Kedelai: Antara Harapan dan Kenyataan. Forum Penelitian Agro Ekonomi. 28(1). Hal: 55-68.

David, F. R. 2012. Manajemen Strategis. edisi ke-12. Salemba Empat, Jakarta.

Kementrian Pertanian (Kementan). 2015. Outlook Komoditas Pertanian Tanaman Pangan Kedelai. Pusat Data dan Informasi Pertanian, Kementrian Pertanian. Jakarta.

Lamakampali, T. I. 2015. Sulteng Siapkan Lahan Kedelai 6,500 Hektare. Di akses melalui (http://www. antaranews.com/berita) pada tanggal 09 Desember 2016.

Rachmat, M. (2015). Percepatan Pembangunan Pangan Menuju Pencapaian Ketahananpangan yang Mandiri dan Berdaulat. Forum Penelitian Agro Ekonomi, 33(1). Hal: 1-17.

Rangkuti, F. 2015. Teknik Membedah Kasus Bisnis Analisis SWOT. PT Gramedia Pustaka Utama. Jakarta.

Saragih, B. 2010. Agribisnis Paradigma Baru Pembangunan Ekonomi Berbasis Pertanian. Edisi Ke-3. IPB Press, Bogor.

Yudoyono, S.B. 2013. Mewujudkan Komitmen Politik Pangan. Jakarta: Kantor Staf Khusus Presiden Bidang Pangan dan Energi.

Zakaria, A. K. (2010). Program Pengembangan Agribisnis Kedelai Dalam Peningkatan Produksi dan Pendapatan Petani. J. Litbang Pertanian, 29(4). Hal: 147-153. 